\title{
The Right of Petition and the Typological Forms of Petition in Mexico's Tax Matter
}

\author{
O Direito de Petição e as Formas Tipológicas de Petição em Matéria \\ Tributária do México
}

\author{
Xóchitl Alicia Ramírez Chávez ${ }^{1}$ \\ Francisco de Jesús Cepeda Rincón ${ }^{1}$ \\ Nancy Nelly González Sanmiguel ${ }^{1}$ \\ ${ }^{1}$ Facultad de Derecho y Criminología de la Universidad Autónoma de Nuevo León, \\ San Nicolás de los Garza, Nuevo León, México
}

\begin{abstract}
The following paper analyzes one of the most important freedoms in any nation that deigns to be a Rule of Law: The Right of Petition. Considered as a subjective right of a public nature, it will be analyzed through the main legal norms that regulate it in Mexico, as well as the response time and the agreements due to notification that the authority must issue to complete and fully respect the exercise of this right.
\end{abstract}

Keywords: Right of Petition. Negative Fiction. Positive Fiction. Right of Petition Case Law. Trial Court. Consultation.
Resumo: Este artigo analisa uma das liberdades mais importantes em qualquer nação que seja digna de ser um Estado de Direito: o Direito de Petição. Considerado um direito subjetivo de natureza pública, ele será analisado, neste artigo, por meio das principais normas legais que o regulam no México, bem como o seu tempo de resposta e os acordos decorrentes da notificação de que a autoridade deve emitir para cumprir e respeitar integralmente o exercício desse direito.

Palavras-chave: Direito de Petição. Ficção Negativa. Ficção Positiva. Direito de Petição Jurisprudência. Tribunal de Julgamento. Consulta.

Recebido em: 29/06/2020

Revisado em: 02/07/2020

Aprovado em: 07/07/2020 


\section{Right of Petition}

Among the guiding principles of State activity is the Rule of Law whose fundamental characteristic is constituted by the fact that the public nature's subjective rights of the governed are recognized and protected by the fundamental and supreme norm of all legal positive systems, that is, the Constitution.

One of these prerogatives, better known now as Human Rights, is constituted by the right of petition, which can be considered as a faculty recognized by the State, and defined as one of the fundamental rights of every person to address the authorities by submitting an application and obtaining a solution on said claim.

Its nature resides within the class of subjective law, understood as the power to do or to lawfully omit something else, which shows that we are facing a right of freedom that may or may not be exercised depending on the interest or need in relation to the sphere of competence of some authority.

When the governed so decide and goes to some authority through the exercise of this request, a legal relationship is generated between the latter and the governed, that is, a relationship regulated by law between two people, one with the quality of active subject (petitioner) who has the right to request something that is within the powers that fall to the authority to whom the petition is addressed (taxable person) with the corresponding obligation of the latter to give an answer to what is intended.

Since the Public Administration or even any other authority (legislative or judicial) who is in the position of having to resolve a petition and therefore develop a materially administrative function is within this legal relationship, this bond is called legal-administrative relationship

This relationship must be subject to another of the basic foundations of state activity, this being the principle of legality, which suggests that every act of the State must be carried out in accordance with the law, that 
is, respecting each and every one of the legal provisions or regulations that regulate their actions in each case; remember here the general principles that distinguish private from public law, in this, the State can only do what the law expressly allows each authority as its own power, in that, individuals can do anything that is not expressly prohibited or sanctioned by the law.

In regards to the matter of the right of petition, it is also very interesting to bear in mind that in antiquity the individual was considered to be of little importance as compared with the sovereign State and its value was only so far as it could serve the purposes of State and therefore, between State and subjects there could only exist power relations; on the other hand, from the birth of the conceptualization of the Rule of Law, it is feasible to speak of legal or legal relations existing between the ruler and the ruled. With all the reference frameworks pointed out in the preceding paragraphs, we will at once go-ahead to conduct a brief analysis of the right of petition.

The right of petition is enshrined in its original form in Article 8 of the Political Constitution of the United Mexican States in the following terms:

Public officers and employees will respect the exercise of the right to petition provided that petition is made in writing and in a peaceful and respectful manner. Regarding political petitioning, only citizens have this right. Every petition must be decided in writing by the authority to whom it was addressed, who has the duty to reply to the petitioner within a brief-term. (POLITICAL CONSTITUTION OF THE UNITED MEXICAN STATES, 2020)

In accordance with this, any natural or legal person who at a certain time has the character of being governed is the holder of the legal power to address any of the authorities and request by means of the formulation of a written request, consistent with the field of powers of the public entity to which it is addressed. Although it is true that the Constitution does not require or limit that the right of petition contains claims according to the competence of the authority to which they are directed, it is for reasons of 
pragmatic order that in all cases it should be so, since its logic indicates that if we promote something before the authority it is because we need a resolution of this and not obtain from it an answer that is only to indicate that it is not the competent authority to solve, thus reducing the time that could be valuable to remedy, vent or complete a need or difficulty.

On the other hand, the State and its authorities (civil servants and public employees), due to the legal bond created by virtue of the subjective public right established in above-mentioned Article 8, receive the positive legal obligation and duty to do, consisting of the execution of issuing a written agreement that responds to the request submitted by the subordinate to the state action. In a similar sense, the Supreme Court of Justice of the Mexican nation has ruled in Isolated Ruling sustained by the Second Chamber, visible on page 117, Volume CXV of 5th Period published in the Federal Judicial Weekly, whose heading and part of the text says that: "The guarantee provided by Article 8 of the Constitution [...] does impose upon the authorities the obligation to give any request made in writing, whether it is well or poorly formulated, an agreement also in writing".

Now, giving an answer does not imply responding in a favorable way, the authorities have the obligation to attend all the pleas that are presented to them and to produce a response consistent with what is requested, but it does not mean that the authority must resolve them in a certain sense, therefore, the right of petition established in Article 8 of the Constitution is an abstract right, that is, it only constitutes a possibility of requesting something from the authorities and not that they resolve by recognizing the petitioner in any specific sense. This has been resolved by the federal courts in the following terms: "The guarantees enshrined in article $8^{\text {th }}$ constitutional tend to ensure a provision on what is requested and not to resolve requests in a certain sense".

In addition and as mentioned above, as all State activity is subject to the principle of legality, the authority before whom a petition was exercised is also obliged to resolve in accordance with the regulations that may be applicable to the case in the sense that is deemed appropriate, which will not necessarily always be favorable to the petitioner; being, of 
course, the petitioner's rights to consequently challenge as appropriate, by the ordinary means established by law for such effects, any agreement issued in violation of the law or with a deficiency in its legal basis and that cause harm to the governed.

Regarding other constitutional elements that characterize the right of petition, with respect the way in which any request should be made before the authority, we have that it must be voiced itself in writing, the petitioner must obtain testimony that it was delivered to the authority by means of a copy of the acknowledgment of receipt, in order to be able to claim in case of omission by the authority regarding your request.

It must be formulated in a peaceful manner, this is without using any violence mechanism or threat against authority and also in a respectful way, that is, addressing the authority with courtesy, composure and property, that is to say, by way of civic virtue.

Likewise, the response from the authority must complete the following aspects: Answer in writing, which means that, if the authority responds verbally or in any other way that is not documented, it is in the presence of violation of what is required by the supreme norm and, obviously, its content must be consistent with what is requested in the event of the interested party's request.

Regarding whether it should be disclosed to the interested party, it is considered that the State organ has a constitutional obligation to inform the petitioner of the agreement that corresponds to his request so that this response achieves legal effectiveness, so it is not enough to that the authority has given a reply to the petitioner, but that the applicant must be duly notified, giving the applicant the original document, otherwise this constitutional right is not satisfied.

Therefore, the petitioner must write down an address, including electronic means of location such as email to receive notifications. The general rule indicates that it is enough that a petition meets the minimum requirements indicated in the supreme law, however, in the area of Tax Law, which is highly technical, the additional requirements that must be taken as an example for any type of request they appear in 
Article 18 of the Mexican Federal Tax Code, this in order to facilitate the communication of the response from the authority, as well as to let it be promptly known by the interested party.

Another especially crucial element is the obligation that all the State authorities must receive the petition briefs presented to them by the governed. If any State organ arbitrarily refuses to respect the exercise of this right, it assumes a responsibility that may derive even in the form of a criminal charge for a constitutional violation, this in accordance with the provisions of the Federal Criminal Code.

Regarding the expression used in the Constitution about giving an answer in a short term, it has elicited the most varied enforcement of our highest court that have not ventured in chronologically delimiting such an idea, but on the contrary have established a series of variations regarding for the duration of what should be interpreted as a "short term", for example, terms have been defined that range from three, five, ten and fifteen days, to terms of several months.

On the contrary, it is true that it would be impractical to previously and definitively determine a certain deadline for all types of requests that could be outlined, since the possibility of responding by the authorities depends on each specific case and, therefore, this must vary according to each particular matter, and the necessary time that is rationally required by the authority must elapse to formulate its answer in each case.

Due to all these considerations, the original idea of the text contained in the current eighth Article was finally observed, which, although it is true that it remains undefined of what should be understood for a short term, it is fair for this timeframe to be adjusted in each case, according to the nature of the request, as well as the procedures that the authority must complete in each situation to be in the real possibility of issuing its respective pronouncement.

However, in the absence of a specific term, in some laws, firstly of tax nature and later expanded to certain areas of administrative law, an attempt has been made to solve this problem by establishing fixed and specific deadlines for the resolution of the different forms of petitions 
that the governed could send them and this has resulted in the effects of the omission (administrative silence) of the authority for not giving an answer within the term that in each of these cases the respective legislation pronounces, which is known as affirmative or positive fiction and negative fiction.

Such is the case, for example, of Article $37^{\text {th }}$ from the Federal Tax Code, which establishes that the pleas or requests made to the fiscal authorities must be resolved within a period of three months; once said period has elapsed without notification of the resolution, the interested party may consider that the authority resolved negatively and, therefore, interpose the means of defense.

Another case in administrative matters is found in number 17 of the Federal Law of Administrative Procedure, which establishes that, unless another general legal or administrative provision establishes another term, the time for the agency or decentralized body to resolve what corresponds may not exceed three months. After this, the resolutions for the promoter will be understood as negative.

Precisely the Trial Court of the highest judiciary, has determined on the right of petition, which is composed of the following elements:

The so-called "right of petition" [...] is the individual guarantee enshrined in Article $8^{\text {th }}$ of the Political Constitution of the United Mexican States, according to which any governed person who files a petition with an authority has the right to receive a response. Thus, its exercise by the individual and the correlative obligation of the authority to produce a response, characterized by the following elements: A. The request: it must be formulated in a peaceful and respectful manner, addressed to authority and the evidence that it was delivered; In addition, the petitioner must provide the address to receive the response. B. The answer: the authority must issue an agreement shortly, understanding it to be the one that is rationally required to study the petition and agree to it, which will have to be consistent with the request and the authority must notify the agreement to the petition in personally to the governed in the domicile that he indicated for such purposes, without there being an obligation to resolve in a certain sense, that is, the exercise of the 
right of petition does not constrain the authority before whom it was formulated, to provide in accordance with what is requested by the petitioner, but is free to resolve in accordance with the regulations that are applicable to the case, and the response or procedure given to the petition must be communicated precisely by the authority before whom the right was exercised, and not by another diverse. (DERECHO DE PETICIÓN, 2020)

Lastly, it must be borne in mind that there is only one constitutional limitation on this petitionary right, and that is that foreign persons do not enjoy this right in matters of a political nature and this criterion is reinforced by the provisions from Section $\mathrm{V}$ of the Article 35 of the Mexican Constitution, remaining this right to intervene in the political affairs of the country reserved only to people who have the quality of Mexican citizens.

Although the concept contrary to foreigner is the nationality, the terminology used by the Constitution is considered to be correct from a practical point of view, since in order to present the document where the right of petition is exercised, it must comply with the essential elements and validity of any legal act and one of them is the ability to exercise for yourself the rights and obligations that are enjoyed within this legal system, that in the case of Mexican citizens, the age required to enjoy rights as such, in addition to being Mexican and having an honest way of living, it coincides with that of obtaining the age of majority established by Mexican civil legislation for the acquisition of exercise capacity, which is eighteen.

\section{Typology of the Forms of Petition}

The right of petition can take many different forms, ranging from complaints, allegations and claims, through the so-called requests or right of petition, to queries, appeals and pleas depending on the branch of Law in question, as well as the type of interest or motivation that the governed manifests to the authority. The following section will only deal with the types that the different forms of right of petition in Tax matters may have, 
for which the examination of the relative provisions of the Federal Tax Code of the United Mexican States will support.

It is common for taxpayers to have to go to the tax authorities with petitions of different matters; it may well be to request the tax return of some amount of money paid in excess and, therefore, in favor, such as to request the prolongation of a term or an extension for the fulfillment of any contribution or the filing of any remedy.

All this diversity of forms of presenting before the tax authority with a request is known as a plea or petition in tax law and in general terms all the principles that the Mexican Constitution establishes for the proper exercise of this right must be respected, but as it had been previously pointed out, since it is a branch of law that requires the most technical rigor, the minimum formal requirements that must be met to obtain a favorable response, if applicable, and swift by the tax authority.

For this, firstly, an analysis of Article 34 which regulates the Federal Tax Code will be required, as it shows one of the modalities of the right of petition; the article is the right to formulate tax consultations, of which the most common refer to requests that the administrated direct to the tax authority to know the position or criteria of the tax body regarding a certain case or confirm a criterion that has tax implications for said taxpayers.

The filing of Consultations must satisfy the secondary requirements that ordinary tax law has imposed on those administered, in addition to those said by the Constitution. In this sense, Article 18 of the Federal Tax Code establishes as minimum requirements to present the promotion by means of a digital document that contains an advanced electronic signature that must be sent by the electronic means authorized by the tax administration system, that is, to the Tax inbox and indicate name, entity or company name of the applicant; fiscal address and the corresponding code in the federal taxpayer registry, authority to whom it is addressed, purpose of the promotion and email address to receive notifications, the latter requirement without which it will be considered not filed. 
Said consultations must be about real and concrete situations, that is, not about hypothetical cases presented individually, since each case has its own particular circumstances; likewise, the tax authority is only obliged to answer if it complies with containing the background and circumstances necessary for the authority to be able to rule on it; that said situation has not been modified after the presentation before the authority and that it is presented before the authority exercises its powers of verification (CÓDIGO FISCAL DE LA FEDERACIÓN, 2020).

In regard to this type are the queries regarding transfer prices whose purpose is for the authority to confirm whether the method used in determining prices is the correct one, in the terms of article 179 from the Income Tax Law, as well as of Article 34-A of the Federal Tax Code.

Other types of consultations are, for example, those that arise in customs matters regarding the tariff classification, this is for those interested in conducting foreign trade operations when they need to consult the customs authority when they consider that the goods can be classified into several fractions Tariffs and regarding the customs value that is intended to request consultation on the applicable valuation method or the elements that must be taken into account to determine the value of customs goods. The requirements are in articles 18 and 18-A from the Federal Tax Code as it is a supplementary rule to the Customs Law, as recognized in Article 1 of the same (LEY ADUANERA DE LOS ESTADOS UNIDOS MEXICANOS, 2020).

Another criterion that serves to classify the types of pleas or requests in tax matters is the one that refers to the effects that may be disenthrall on future instances, for example, taxpayers have the right to request the return of the amounts of money that have been paid improperly, but once such plea has been exercised, the petitioner can no longer choose to request compensation for said amounts, since this right is automatically canceled when the request for refund is raised, as established in Article 23 paragraph 4 of the Federal Tax Code. These are known as pleas (requests) that condition later pleas. Another plea of this nature is the appeal for revocation and the nullity judgment, for this purpose Article 120 of the aforementioned provision provides that 
the filing of the appeal for revocation shall be optional for the interested party before going to the Federal Court of Tax and Administrative Justice, which means that any of these options chosen by the taxpayer in case they have an interest in contesting any act of the tax authority, must continue until their resolution by the means first selected. The petition or plea filed through the revocation resource, has the effect of conditioning and restricting the possibilities of other instances or later requests.

There are other taxonomic criteria for petitions, according to the title in which they are supported, thus we have petitions by grace, within which are all those requests that are only under the provisions of Article 8 of the Constitution in such a way that they are satisfied with the only response that the authority has to issue (act of grace), regardless of the meaning of this, for example requests whose objective is to obtain the authorization of the tax authority to make payment in installments, either in installments or deferred, of omitted contributions and their accessories, as long as the taxpayers satisfy the requirements established in Article 66 of the Tax Code.

Diverse is the case of motivated petitions, so called because the basis of such pleas or requests does have an origin, cause, drive or reason for being, which at the same time constitutes the confidence and security that the request is resolved in favor of the interested party, as long as it is verified that they are supported in a just title to achieve the recognition of the authority to that right. The option to choose the refund of taxes unduly paid at the time of making the annual return, for example from a taxpayer, natural person, in whose statements obtain evidence of the amounts that were in their favor, after a fiscal year, is part of this set.

In relation to all these forms of exercising the right of petition in tax matters, it only remains to analyze some rules that guide the criteria to solve any inconvenience that may arise during the exercise of this right. The first problem has to do with who are the legitimate subjects to send an application. The general rule dictates that any person, whether natural or legal, can file a petition, by itself or through its duly accredited representative regarding the legal personality with which it intervenes, following the rules of private law regarding the ways and means that they 
must be complied with in the case of the granting of mandates, power of attorney or any other means of legal and/or voluntary representation, business management being absolutely prohibited as established in Article 19 of the Tax Code in its first statement. Likewise, the person who submits a request can authorize others in that act so that in their name and representation they can receive notifications and even carry out some promotions that are directly and immediately related to the matter for which they were authorized, as provided Article 136 of the same legal system.

Regarding the way in which the different instances and petitions in tax matters must be presented, Article 31 of the Tax Code establishes that individuals must submit requests regarding federal taxpayer registration, declarations, notices or reports, in digital documents with advanced electronic signature and through the electronic media formats and with the information indicated by the Tax Administration Service through general rules.

\section{The Public Administration's Obligations Before the Right of Petition}

Silence speaks, since in it there lays an implicit response to a request, in that sense in Administrative Law we speak of administrative silence, when the stipulated time has passed for the Public Administration to respond to the governed regarding a petition or proceedings, when reference is made to this administrative silence, we refer to

$[\ldots]$ that doctrine according to which, the legislator gives a concrete value to the inactivity, inertia or passivity of the administration when faced with the request of an individual, making it presume the existence of an administrative decision, sometimes negatively and sometimes affirmatively. (SILENCIO ADMINISTRATIVO Y AFIRMATIVA FICTA. SU ALCANCE Y CASOS DE APLICACION EN EL REGIMEN JURIDICO MEXICANO, 2020) 
This administrative response as mentioned above can be in the negative or in the positive sense, which is configured in a fiction of the law, known as negative fiction and positive fiction respectively, the same being a fiction of the Law, are not treated of an act, "[...] because every act supposes a manifestation of will and in the case of silence there is no such will" (VILLALBA PAUDO, 2017, p. 6).

The two senses of administrative silence have their peculiarities, and both have their specific use in Mexico's tax matter. To fully see both, we will analyze each sense of these responses.

\section{Negative Fiction}

In tax matters, a responsibility is generated for the Public Administration for not attending to the requests or promotions of those administered within the period established in the legislation, thus generating the figure of the negative refusal through which it is understood that said process has been resolved in the opposite direction to the requests of the interested party.

To consider that public servants must attend to their writings in an effective and impartial manner constitutes a guarantee for the administrators, as long as they are real questions and concrete facts, it must be understood with the fictitious refusal "[...] that the instance was unfavorably resolved to the interests of the particular [...]" (RUEDA DEL VALLE, 2000, p. 48) provided that said briefs meet the characteristics for them to be answered by the authority.

In this sense, even when the authority has the obligation to reply to said briefs and the period of three months to give an answer established by the Federal Tax Code has elapsed "[...] there is an additional element, constituted by the exercise of the action in its against, since even though the first two elements have been fulfilled, if the individual does not contest said refusal, the authority may issue its express resolution [...]" (DELGADILLO GUTIÉRREZ; ESPINOSA, 2005, p. 290), even if time has elapsed and the interested party does not contest through the judicial 
channel, he can await the determination of the Tax Authority regarding said consultation.

Now, the negative refusal does not become an administrative act, or a resolution, it is simply the sense in which the authority does not answer in the indicated term, the response being required by the jurisdictional route, that is, by means of the challenge through which the corresponding resolution is determined by the court.

Within the Federal Law of Administrative Procedure, article 17 says that:

Unless another general legal or administrative provision proves another term, the time for the agency or decentralized body to resolve what corresponds may not exceed three months. Once the applicable term has elapsed, the resolutions will be understood as negative to the promoter, unless otherwise provided in other legal or administrative provisions of a general nature. At the request of the interested party, proof of such circumstance must be issued within two business days following the presentation of the respective request before whom it must resolve. In the event that the refusal is appealed for lack of resolution, and this in turn is not resolved within the same term, it shall be understood as confirmed in the negative sense. (LEY FEDERAL DE PROCEDIMIENTO ADMINISTRATIVO, 2020)

Said article, in addition to confirming the time the authority has to answer in administrative matters, establishes that if in said request any data is missing or that it does not comply with the requirements that are requested, the authority must request it only once by means of a written document, indicating in the same that it is necessary to carry out said procedure, giving a term of not less than five days once it has been notified so that the interested party can present the missing information, said period of five days may vary according to the corresponding legislation to the procedures before the dependencies or decentralized organisms, without attaching the required documents, then said procedure will be rejected. 
Likewise, the term given to the authority to respond to said procedures begins to count immediately on the business day following the presentation made by the individual, from there the term begins to generate a response from the Public Administration or whether the socalled silence is generated, in a particular case because it is negative fiction in tax matter.

\section{Difference Between Negative Fiction and Administrative Silence}

As mentioned above, despite the fact that the Mexican administrative law doctrine on administrative silence contains the meanings that silence can have, that is, the affirmative fiction or a negative fiction, these last two figures correspond to legal fictions with determined purposes, in this sense, the great difference between these fictions and the administrative silence is that the latter "[...] is presumed as a manifestation of will and has the effects of a declared act [...]" (GABINO FRAGA, 2016, p. 274), while the fictional refusal arises after the expiration of three months to respond to a query to the tax authority, with which it will have to be resolved in a negative sense, in that sense said figure helps us to speed up the response considering itself as a fiction of that query or request.

One of the starting points about the difference between the negative fiction and the administrative silence derives from the configuration of the same within the rules, since the negative refusal is contained in the Federal Tax Code, in its article 34 that verbatim points out that "the tax authorities must answer inquiries made by individuals within a period of three months from the date of submission of the respective request"(Código Fiscal de la Federación ), then establishing in article 37 that

[...] the pleas or requests made to the tax authorities must be resolved within a period of three months; once said period has elapsed without notification of the resolution, the interested party may consider that the authority resolved negatively and interpose the means of defense at any time after said term, as long as the 
resolution is not issued, or wait for it to be issued. (CÓDIGO FISCAL DE LA FEDERACIÓN, 2020)

Within article 37 of the Federal Tax Code, it is stated that said period can be prolonged to eight months in the case of consultations made on the use of the methodology for determining the prices, compensation amounts, of operations with the related parties, as well as the term begins to be computed in the event that there has been a requirement when complying with what was requested by the authority.

Administrative silence on the other hand is more closely linked to the right of petition found in the Political Constitution of the United Mexican States in article number 8, which establishes that "[...] every petition must be decided in writing by the authority to whom it was addressed, who has the duty to reply to the petitioner within a brief term [...]" (CONSTITUCIÓN POLÍTICA DE LOS ESTADOS UNIDOS MEXICANO, 2020), in this sense, administrative silence violates the right of petition, whose scope is broader because it can be requested from any public official or employee while the conformation of the negative fiction is concentrated in the tax authorities.

Likewise, there is a difference between the two terms that lies in the filing of the challenge through the courts. Because administrative silence violates a constitutional right, the ideal way to challenge it is through the Amparo Trial, while the figure of the negative fiction as contained in the Federal Tax Code is challenged through the nullity judgment before the Administrative Justice Court.

Another difference arises with respect to how the two situations are resolved, in that while in administrative silence what is managed through the amparo is the violation of the right of petition is resolved by ordering the corresponding authority to issue it, that is to say a response to such request; on the other hand, with respect to the negative fiction, the competent jurisdictional authority must thoroughly study in which sense the negative fiction was given at the request of the individual.

Thus, both figures have a different matter with respect to the right of petition, since on the one hand, administrative silence is given 
against a constitutional precept, this being a question about the obligation of the Public Administration to respond to what the petitioner requests as long as it is in a peaceful, respectful, written and factual manner, while the negative fiction is configured by the inactivity of the public administration for not responding to a promotion or consultation and is within however, in both cases, the lack of communication from the authority to the individual of what the latter has requested in the course of time is presented, but generating different causes and legal consequences.

\section{Affirmative Fiction}

The affirmative fiction on the other hand is established as a way of carrying out certain procedures before the Public Administrations that permissions, licenses, registrations are granted over time, they must be considered within the regulations so that this type of procedures, this is parallel to the simplification of the processes, because in the event that in the determined time it does not answer the request, it will be understood that the Administration has made such request.

The affirmative fiction in Sarmiento's words reads as:

A principle of law according to which the silence of authority is interpreted in the affirmative. If a company or natural person files an appeal or request with the authority, it is quite common for such to take too long to respond. When the principle of affirmative fiction applies, the lack of response, after a certain time, is legally considered as an approval. This principle represents a guarantee of expedited processing and gives assurance to the applicant that they can plan their actions from a certain date. (SARMIENTO, 1995)

In this sense, the affirmative fiction is configured " $[\ldots]$ in matters that allow it, deadlines for its resolution, establishing that the tacit resolution will be operated in a favorable direction for the interested parties, in the cases that no express resolution is given to the planning of in question, within said period [...]" (DIARIO OFICIAL DE LA FEDERACIÓN, DE 8 DE AGOSTO DE 1984, art. 4, inc. k.), for which 
reason it must be stated within the legislation that such form is expressed in order for it to proceed. Unlike the negative fiction, the figure of the affirmative fiction does produce effects, being opposable to third parties, before the authority or the individual, caused rights contemplated within the regulations.

In order to determine or record that the affirmative fiction exists and has a certification of it, you will have to request before the authority that the certificate is issued, this in accordance with article 17 of the Administrative Procedure Law which says:

At the request of the interested party, proof of such circumstance must be issued within two business days following the presentation of the respective request to the person who must resolve; The same proof must be issued when other provisions provide that once the applicable term has elapsed, the resolution must be understood in a positive sense. (LEY FEDERAL DE PROCEDIMIENTO ADMINISTRATIVO, 2020)

As an example of the affirmative fiction within the Mexican norm, we find in article 28 Bis 4 of the Finance Law for the municipalities of the State of Nuevo León says the following:

The Municipal Treasury will receive the official note of the property acquisition tax and will return to the taxpayer a copy stating its receipt, and must be accepted or rejected within a period of no more than ten business days, counted from the day following the of your presentation. Once said period has elapsed without notification of rejection, the note shall be considered accepted, without prejudice to the powers of inspection that the authority keeps. Once the official note has been accepted, the Municipal Treasury will register the operation, giving the corresponding notice to the Cadastre Directorate of the Secretariat of Finance and General Treasury of the State within 5 business days of said event in order to proceed to the update of the cadastral registry [...]. Once the affirmative fact has been set up, the tax may be consigned by deposit before the Ministry of Finance and General Treasury of the 
State, which in turn, will make the amount of the proceeds available to the Municipality.

Although there are not many examples of the use of the affirmative fiction in Mexican Law, this is because, it may end up conferring different de facto rights at a certain time, since, for example, the case law thesis with respect to the above mentions the following:

In accordance with the nature and the mechanism of payment of the tax on the acquisition of real estate in the State of Nuevo León, the affirmative fact provided for in the aforementioned article translates into the sole acceptance upon receipt of the official note for the consignment of the numerary, in the amount calculated by the taxpayer or notary public, as the case may be, in order to proceed to register the operation in the Public Registry of Property and Commerce, as well as for the modification of the cadastral base, but not in the final resolution in which the administrative authority determines, quantifies or settles the amount to be paid for said contribution. The foregoing, because being a self-determined tax, the tax authority has the powers of verification to establish the final calculation of the amount to be paid. (10a. ÉPOCA; PLENOS DE CIRCUITO; GACETA S. J. F.; LIBRO 14, ENERO DE 2015; TOMO II; p. 1416. PC.IV.A. J/5 A (10a.))

\section{Applicable Measures Against the Negative Fiction and to Enforce the Constitutional right of Petition}

The Public Administration has the obligation to resolve and respond to any request made by individuals, as long as the formalities established in the competent provisions are complied with, however, as mentioned above, administrative silence is also possible, and constitutes a way in which this procedure can be solved, either by means of administrative silence in the sense of the affirmative fiction or that of the negative fiction, understanding that: 
Administrative silence has been considered as a technique established by the law due to the lack of resolution within the administrative procedures, by means of which the requests addressed to the administration can be considered estimated (positive silence) or rejected (negative silence). (CIENFUEGOS SALGADO, 2004, p. 240)

However, in Mexico the application of the affirmative fiction is scarce, since in it "[...] the consequence of the inactivity of the administrative body translates into the fiction of considering that the petition has been resolved favorably [...]" (CIENFUEGOS SALGADO, 2004, p. 241) and it is considered that they go hand in hand possible risks in its adoption and the particularities that it presents, in this sense

[...] there has not been a frank reception in federal administrative legislation, as to date there is no precept where it is included as a general rule applicable to all cases of requests or files instructed by public bodies at the request of individuals. (SILENCIO ADMINISTRATIVO Y AFIRMATIVA FICTA. SU ALCANCE Y CASOS DE APLICACION EN EL REGIMEN JURIDICO MEXICANO, 2020)

The administrative silence arises "[...] to allow the administered access to administrative and jurisdictional resources in the event that the administration does not resolve the procedure of which it is a part" (VILLALBA PAUDO, 2017, p. 6). Within Mexican law, it is contemplated that the measures that are applicable in tax matters against administrative silence in its two forms, both the affirmative fiction and the negative fiction are the nullity judgment and the amparo judgment.

\section{Nullity Claim}

When there is a negative fiction, the only means of challenge that can be made in tax material is through the establishment of a nullity claim before the fiscal court, based on section IV of article 11 of the Organic Law of the Federal Court of Tax and Administrative Justice, since: 
When the negative fiction of the administrative authority is indicated as an act claimed in the bi-instance amparo trial, it is required to observe the principle of definitiveness and, therefore, the ordinary means of challenge or the respective nullity judgment must be exhausted, the which cannot refer to anything else, but to the basic matter of what is expressly intended by the individual and what is denied exactly by the authority, since negative silence is a legal fiction with exclusively procedural effects, whose purpose is to overcome the consequences of the inactivity of the administration, opening the way for administrative contentious judgment for the exclusive benefit of those administered. (LEY ORGÁNICA DEL TRIBUNAL FEDERAL DE JUSTICIA FISCAL Y ADMINISTRATIVA)

It is important to take into account that, while the negative fiction is a legal fiction that does not replace the will of the administrative authority, it cannot be argued that the negative statement is unfounded and unmotivated so that, for this reason, the amparo proceeding can proceed, "since in the case of negative fiction, the law is not substituted in the will of the administration, directly producing an act of negative silence - which does occur in the case of positive silence, when so provided for; hence, the fictional refusal cannot be above the public order that is the foundation of the causes of inadmissibility".

\section{Amparo Trial}

The amparo trial on the other hand corresponds to the legal means through which the individual can challenge a resolution issued through the expression of administrative silence, as mentioned above, it is required to have exhausted the remedy established by ordinary law, that is to say the instances in the nullity claim to be able to go to the indirect amparo trial when there is silence on the part of the public administration, with the exception of the direct invocation of a violation of Article 8 of the Federal Constitution of the United Mexican States, in the which excludes the need to exhaust the principle of definitiveness by resorting to the ordinary resource in favor of the right of petition, since article 8 states that: 
Article 8. Public officers and employees will respect the exercise of the right to petition provided that petition is made in writing and in a peaceful and respectful manner. Regarding political petitioning, only citizens have this right. Every petition must be decided in writing by the authority to whom it was addressed, who has the duty to reply to the petitioner within a brief-term. (CONSTITUCIÓN POLÍTICA DE LOS ESTADOS UNIDOS MEXICANOS)

In Mexico, the rights enshrined in the Constitution are protected by the amparo lawsuit. In the case of the right to petition mentioned above, the right to petition is not violated as such, but the failure to obtain a response, as proven in the second paragraph. of the 8 th article.

\section{Conclusion}

As in many Latin American countries, in Mexico the questions regarding the right of petition, administrative silence and the legal fictions of the negative and the positive fiction remain part of the case law debates, since on the one hand the Public Administration has the obligation to carry out their activities, as well as answering the requests of individuals quickly and efficiently, not only to comply with the rule of law, but also to consolidate a democratic state that is managed under the principle of transparency in which governed may know through the right of petition the state information and on the other, the State has the obligation to give a broader protection to human rights through the pro persona principle and the broader interpretation of the law.

In regard to these legal fictions in tax matters, there is still a long way to go because there are still challenges that must be safeguarded to maintain the principles of legal certainty in the State and the principle of legality; for example, there is an inconsistency within the Federal Tax Code due to the fact that within its number 18-A that it refers to: "[...] promotions that are presented to the tax authorities in which queries or requests for authorization or regime are made in the terms of articles 34, 34-A and 36 Bis of this Code, for which there is no official form, must comply, in addition to the requirements established in article 18 of this 
Code, with the following [...] When not the requirements referred to in this article are fulfilled, the provisions of article 18, last paragraph of this Code, shall be followed [...]"'(CÓDIGO FISCAL DE LA FEDERACIÓN), while the last paragraph of that article refers to the following; "The provisions of this article are not applicable to the declarations, registration requests or notices to the federal taxpayer registry referred to in article 31 of this Code"(Código Fiscal de la Federación), since the applicant has no obligation to comply with said requirements because there is no consequence, since the last paragraph of article 18 does not impose any sanction, in said writing the authority must resolve according to the documentation filed because it cannot establish a requirement, nor reject it for not presenting said requirements and this is due to a change in the wording of the provision and that article 18-A was not modified to the paragraph that should understand that it would be antepenultimate paragraph of the article 18 which establishes that if the requirements are not met, it will be considered as not presented.

Likewise, despite the existing resolution of the Supreme Court of Justice of the Nation, there is still a debate on whether the fundamental right of petition is violated with the negative fiction, the Supreme Court of Justice in an isolated ruling of the First Court Collegiate in Administrative Matters of the Sixth Circuit established the following:

The negative fiction, which implies that the silence of the fiscal authority before a plea or petition formulated by the taxpayer, extended uninterruptedly during the aforementioned three-month term, generates the legal presumption that it resolved against the interests of the petitioner, circumstance that gives rise to the procedural right to file the appropriate means of defense against that tacit negation, or to wait for the authority to issue the respective resolution. Thus, the term provided for in the first paragraph of article 37 from the Federal Tax Code, when bind to the figure of the negative fiction in the event of silence of the authority, allows guaranteeing a definition to the individual on the request made, either through an answer expressly, or implicitly, which also translates into giving you certainty about the existence of a time limit after which you will be able to assert the appropriate means 
of defense in relation to the merits of the request, since with such fictional figure also determines the litigation on which, eventually, the means of defense that, if it deems appropriate, enforces the individual will be involved. Consequently, taking into account the two prominent considerations, and in exercising the constitutional control initially referred to, it must be concluded that the content of the normative portion of merit does not affect the right of petition recognized in constitutional Article 8, and that the corresponding legal problem is solved with the examination carried out based on the conforming interpretation thereof. ([TA]; 10a. ÉPOCA; T.C.C.; S.J.F. Y SU GACETA; LIBRO VIII, MAYO DE 2012; TOMO 2; p. 1.861. VI.1o.A.21 A (10a))

Therefore, it does not consider that the negative fiction to be violative by matter that within constitutional article 8 it does not specify the specific term that the authority must meet to give an answer, however, in tax matters following the Federal Tax Code, there is an assumption in which it is determined that the procedural law must be observed to manage or wait for the resolution issued by the tax authority.

\section{References}

10a. ÉPOCA; PELONOS DE CIRCUITO; GACETA S. J. F.; Libro 14, Enero de 2015; Tomo II; p. 1416. PC.IV.A. J/5 A (10a.).

CIENFUEGOS SALGADO, David. El derecho de petición en México. [S.l.]: UNAM, 2004.

CONSTITUCIÓN POLÍTICA DE LOS ESTADOS UNIDOS MEXICANOS.

CÓDIGO FISCAL DE LA FEDERACIÓN DE LOS ESTADOS UNIDOS MEXICANOS, 2020.

DELGADILLO GUTIÉRREZ, Luis Humberto; ESPINOSA, Manuel Lucero. Compendio de Derecho Administrativo. Porrúa, México: [s.n.], 2005. 
GABINO FRAGA, Magaña. Derecho Administrativo. Porrúa, México: [s.n.], 2016.

LEY ADUANERA DE LOS ESTADOS UNIDOS MEXICANOS. 2020. LEY FEDERAL DE PROCEDIMIENTO ADMINISTRATIVO. 2020. Available in: www.diputados.gob.mx/LeyesBiblio/pdf/112_180518.pdf. Available in: Feb. 152020.

LEY ORGÁNICA DEL TRIBUNAL FEDERAL DE JUSTICIA FISCAL Y ADMINISTRATIVA. 2020.

SILENCIO ADMINISTRATIVO Y AFIRMATIVA FICTA. SU ALCANCE Y CASOS DE APLICACION EN EL REGIMEN JURIDICO MEXICANO. 2020. Available in: http://sjf.scjn.gob.mx/sjfsist/ Documentos/Tesis/231/231752.pdf. Access in: Feb. 152020. RUEDA DEL VALLE, Iván. La Negativa Ficta en materia fiscal federal. Themis, México; [s.n], 2000.

SARMIENTO, Sergio. Artículo Afirmativa ficta. Revista Expansión, agosto de 1995.

SUPREMA CORTE DE JUSTICIA DE LOS ESTADOS UNIDOS MEXICANOS. Semanario Judicial de la Federación. Marzo de 2011. Derecho De Petición. Sus Elementos. Tesis: XXI.1o.P.A. J/27, Tomo XXXIII, Novena Época, p. 2167. Available in: https://sjf.scjn.gob.mx/ sjfsist/paginas/Tesis.aspx. Access in: Feb. 152020.

[TA]; 10a. ÉPOCA; T.C.C.; S.J.F. y su Gaceta; Libro VIII, Mayo de 2012; Tomo 2; Pág. 1861. VI.10.A.21 A (10a.).

VILLALBA PAUDO, Laura. EI Silencio Administrativo. UAH, 2017. p. 6. Available in: https:/ebuah.uah.es/dspace/bitstream/ handle/10017/32539/El\%20Silencio\%20Administrativo\%20-\%20 Laura $\% 20$ Villalba\%20Puado.pdf?sequence $=1 \&$ is Allowed $=y$. Access in: Feb. 152020. 
Xóchitl Alicia Ramírez Chávez is a Doctor of Law with Summa Cum Laude mention from the Faculty of Law and Criminology of the Autonomous University of Nuevo León, full-time professor of Constitutional Law and Civil Law and Holder of Cultural Diffusion from the same Faculty; Urban Law Advisor for public administration; and Professor of Arts with a specialty in the Teaching of Mexican Folk Dance and Teacher of Music and Piano from the Monterrey School of Music and Dance of the National Institute of Fine Arts.

E-mail:xarch1105@gmail.com

Endereço profissional: Facultad de Derecho y Criminología de la Universidad Autónoma de Nuevo León, San Nicolás de los Garza, Nuevo León, México. https://orcid.org/0000-0002-3542-3658

Francisco de Jesús Cepeda Rincón is a Doctor of Law from the Faculty of Law and Criminology of the Autonomous University of Nuevo León. Bachelor of Philosophy and Humanities. Master's in political science Professor at the Faculty of Law and Criminology of the Autonomous University of Nuevo León. Research director at Paso de Esperanza AC.

E-mail: fcojesuscepeda@gmail.com

Endereço profissional: Facultad de Derecho y Criminología de la Universidad Autónoma de Nuevo León, San Nicolás de los Garza, Nuevo León, México. https://orcid.org/0000-0002-4939-7702

Nancy Nelly González Sanmiguel is a Doctor of Law from the Faculty of Law and Criminology of the Autonomous University of Nuevo León, full-time professor at the same Faculty.

E-mail: nancygonsa09@hotmail.com

Endereço profissional: Facultad de Derecho y Criminología de la Universidad Autónoma de Nuevo León, San Nicolás de los Garza, Nuevo León, México. https://orcid.org/0000-0001-9589-2192 